\title{
PENERAPAN MODEL TEAM GAMES TOURNAMENT (TGT) UNTUK MENINGKATKAN HASIL BELAJAR MATEMATIKA KELAS IV KHUSUSNYA PADA MATERI PEMECAHAN MASALAH BILANGAN ROMAWI DI SDN PAGENTAN 5 TAHUN AJARAN 2016/2017
}

\author{
Nanik Herliani \\ Sekolah Dasar Negeri Pagentan 05 Singosari, Malang \\ E-mail: nanik.herliani76@gmail.com
}

\begin{abstract}
Mathematics learning in fourth grade SDN Pagentan 5 on problem solving material of roman numerals, not yet fully centered on student. This resulted learning process is not yet optimal. The study aimed to describe the application of the TGT model in improve the Mathematics learning of fourth grade SDN Pagentan 5 Singosari Malang and describe the student activity in learning to reach the learning outcomes. The research was conducted in the fourth grade of SDN Pagentan 5 Singosari Malang Regency. The research design used was Classroom Action Research developed by Kemmis and Tagard. The data collection techniques used in this resecarh is observation, documentation and test techniques. It showed that TGT model successfully applied in learning mathematics so that can increase activity and result learn student. Observation's result of the application of learning has increased by $12.5 \%$ from UH to cycle I. Student activity observation's result showed improvement from cycle I to cycle II by $22,5 \%$. By using the TGT model the learning outcomes from cycle I to cycle II increased by $22.5 \%$.
\end{abstract}

Key word: play (TGT), mathematic, roman number

\begin{abstract}
ABSTRAK
Pembelajaran Matematika di kelas IV SDN Pagentan 5 pada materi pemecahan masalah bilangan romawi, belum sepenuhnya berpusat pada siswa. Hal inilah yang mengakibatkan hasil belajar siswa kurang optimal. Tujuan penelitian ini adalah mendeskripsikan penerapan model TGT dalam meningkatkan pembelajaran Matematika kelas IV SDN Pagentan 5 singosari kabupaten Malang dan mendeskripsikan aktivitas siswa dalam pembelajaran guna meningkatkan hasil belajar. Penelitian dilaksanakan di kelas IV SDN Pagentan 5 Singosari kabupaten Malang. Rancangan penelitian yang digunakan adalah Penelitian Tindakan Kelas yang dikembangkan oleh Kemmis dan Tagard. Sedangkan teknik pengumpulan data dengan menggunakan teknik observasi, dokumentasi dan tes. Hasil penelitian menunjukkan bahwa model TGT berhasil diterapkan dalam pembelajaran Matematika sehingga dapat meningkatkan aktivitas dan hasil belajar siswa. Hasil observasi penerapan pembelajaran mengalami peningkatan sebesar $12.5 \%$ dari UH ke siklus I. Hasil observasi aktivitas siswa menunjukkan peningkatan dari siklus I ke siklus II sebesar 22,5\%. Dengan menggunakan model TGT hasil belajar dari siklus I ke siklus II meningkat sebesar 22,5\%.
\end{abstract}

Kata Kunci : permainan (TGT), matematika, bilangan romawi 


\section{PENDAHULUAN}

Guru mengemban tugas yang berat untuk tercapainya tujuan pendidikan nasional yaitu seperti yang diamanatkan dalam Undang - Undang No : 20 / 2003 Tentang Sistem Pendidikan Nasional pasal 3 dijelaskan bahwa " Tujuan Pendidikan Nasional berfungsi mengembangkan kemampuan dan membentuk watak serta peradapan bangsa yang bermartabat dalam rangka mencerdaskan kehidupan bangsa, bertujuan untuk berkembangnya potensi agar menjadi manusia yang beriman dan bertaqwa kepada Tuhan Yang Maha Esa, berakhlak mulia, cakap, kreatif, mandiri dan menjadi warga negara yang demokratis serta bertanggung jawab" (Departemen Pendidikan Nasional Indonesia).

Meningkatkan kualitas pendidikan merupakan tanggung jawab bersama antara guru, siswa, masyarakat, dan seluruh komponen pendidikan (Muljani, 2017). Peran penting guru harus ditunjang keprofesionalan dalam memilih dan mendesain model pembelajaran yang dapat mendorong minat dan perhatian peserta didik dalam belajar, tidak terkecuali minat dan belajar peserta didik dalam pembelajaran matematika.

Berdasarkan pengalaman peneliti di lapangan, sering dijumpai sebagian besar peserta didik kurang atau bahkan tidak tertarik untuk mengikuti pembelajaran matematika. Pelajaran matematika dianggap momok yang menakutkan dan menegangkan, bahkan yang lebih para timbul adanya anti pati hanya mendengar nama pelajaran matematika. Hal mana gambaran diatas menjadikan nilai hasil pembelajaran matematika yang diperoleh peserta didiktidak maksimal yang pada akhirnya standar ketuntasan belajar minimal (SKBM) pada setiap standar kompetensi tidak tercapai. Dari 40 siswa, 23 atau $57.5 \%$ anak tuntas sedangkan 17 atau $22,5 \%$ siswa lainnya tidak tuntas.

Menyadari permasalahan diatas, peneliti tertarik untuk mengangkat masalah yang terjadi, hal mana yang menyebabkan permasalahan. Dengan model Teams
Games Tournament (TGT) dapat meningkatkan hasil belajar yang ditandai dengan adanya minat dan perhatian serta rasa senang dalam pembelajaran matematika. Peneliti memilih model pembelajran aktif, inovatif, kreatif, efektif dan menyenangkan ini dengan harapan peserta didik secara tidak langsung digiring untuk senang terhadap pembelajaran matematika. Rasa senang akan datang tanpa disadarinya, dan rasa takut dan membosankan akan terkikis juga. Harapan yang ada, dengan belajar dalam suasana yang menyenangkan dapat menarik minat dan perhatian siswa dan pada akhirnya nilai pelajaran matematika dapat memenuhi SKBM atau bahkan dapat melampauinya.

Berdasarkan hasil menunjukkan nilai UH siswa kelas IV SDN Pagentan 05 tahun ajaran 2016/2017 pada pokok bahasan Pemecahan Masalah Bilangan Romawi, sebanyak $42,5 \%$ siswa belum tuntas atau belum sesuai SKBM yang ditentukan. Berdasarkan permasalahan tersebut, guru seharusnya mampu menyajikan pembelajaran yang lebih koperatif dan berpusat pada siswa. Dengan demikian siswa lebih tertarik untuk belajar dan mengikuti pembelajaran di dalam kelas. Harapan siswa memiliki ketertarikan pada materi pembelajaran hasil yang dicapai dapat meningkat, sehingga standar SKBM yang ditetapkan bisa tercapai.

Adapun model pembelajaran yang digunakan penulis pada pembelajaran secara umum pada pembelajaran Matematika khususnya adalah metode Permainan (Game). Metode adalah salah satu tipe pembelajaran kooperatif yang menempatkan siswa dalam kelompokkelompok belajar yang beranggotakan 5 sampai 6 orang siswa yang memiliki kemampuan, jenis kelamin, suku bangsa atau ras yang berbeda. Menurut Slavin pembelajaran kooperatif tipe TGT terdiri dari 5 langkah tahapan yaitu : tahap penyajian kelas (class precentation), belajar dalam kelompok (teams), permainan (games), pertandingan (tournament), dan penghargaan kelompok (team recognition). 
Oleh sebab itu, perlu dilaksanakan penelitian untuk mengetahui penerapan model pembelajaran $T G T$ dalam meningkatkan hasil belajar Matematika Kelas IV khususnya pada materi Pemecahan Masalah Bilangan Romawi pada siswa klas IV SDN, Pagentan 05 tahun ajaran 2016/2017.

\section{METODE PENELITIAN}

Pendekatan yang dilakukan dalam penelitian ini adalah pendekatan kualitatif, karena pendekatan ini memenuhi ciri-ciri kualitatif yaitu: (1) Mempunyai latar alamiah sebagai sumber data langsung yakni situasi kelas, penelitian bersikap wajar sebagaimana adanya tanpa dimanipulasi, (2) Peneliti berperan sebagai alat pengumpul data, (3) Analisis datanya bersifat induktif, (4) Bersifat deskriptif karena data yang dikumpulkan berbentuk kata atau kalimat bukan angka, (5) Lebih mementingkan proses dari pada hasil, karena hal-hal yang diteliti lebih jelas pada saat proses belajar mengajar berlangsung.

Adapun jenis penelitian yang dilakukan adalah Penelitian Tindakan Kelas (PTK) dengan model pelaksanaan kolaboratif. Menurut Wiriaatmadja (2005:12) Penelitian Tindakan Kelas adalah kajian sistematik dari upaya perbaikan pelaksanaan praktek pendidikan oleh sekelompok guru dengan melakukan tindakan-tindakan dalam pembelajaran, berdasarkan refleksi mereka mengenai hasil dari tindakan-tindakan tersebut. Untuk mewujudkan tujuan tersebut, PTK ini dilaksanakan berupa proses pengkajian bersiklus atau menggunakan model siklus, yang terdiri dari 2 siklus di mana setiap siklusnya terdapat dua kali pertemuan.

Subjek penelitian atau dapat disebut juga populasi dalam penelitian kuntitatif adalah individu - individu yang mempunyai ciri tertentu (Arikunto, 2002: 90). Subjek yang digunakan oleh penulis pada penelitian ini adalah seluruh siswa kelas IV SDN PAGENTAN 05 pada tahun ajaran 2016/2017, yang berjumlah 40 siswa. Waktu pelaksanaan adalah 4 dan 6 Februari 2017.

Instrumen penelitian adalah alat pada waktu peneliti menggunakan suatu metode (Arikunto, 2002: 121). Instrumen yang digunakan oleh penulis pada penelitian ini adalah lembar observasi dan tes hasil belajar. Lembar obserasi yang digunakan oleh peneliti diperoleh dari hasil pengamatan penulis serta observer yang hadir pada saat penelitian berlangsung. Instrumen ini digunakan untuk mengetahui secara detail dan rinci penerapan metode TGT )pada pembelajaran Matematika pada materi Pemecahan Masalah Bilangan Bulat. Melalui instrumen ini dapat diketahui pula kelebihan dan kekurangan yang terdapat pada saat pembelajaran di kelas berlangsung.

Sementara itu, instrumen tes hasil belajar siswa setelah model TGT diterapkan, berguna untuk mengetahi hasil belajar siswa seama mengikuti pembelajaran di kelas berlangsung. Melalui instrumen ini dapat di ketahui apakah nilai siswa mengalami peningkatan atau tidak. Sebelum melaksanakan tindakan, langkah awal yang dilakukan pada siklus 1 adalah identifikasi masalah yang dihadapi guru dalam proses pembelajaran. Sebelum gambaran tindakan yang akan dilakukan adalah sebagai berikut:

\section{Siklus 1}

\section{a. Perencanaan}

Pada tahap ini guru merencanakan:

1. Menyusun RPP (Rencana Pelaksanaan Pembelajaran)

2. Membuat lembar kerja siswa (LKS)

3. Membuat alat evaluasi (tes)

4. Menyiapkan gambar-gambar tentag Bilangan Romawi

5. Menyusun lembar evaluasi

\section{b. Tindakan}

Setelah rencana disusun dengan matang barulah tindakan itu dilakukan. Pelaksanaan tindakan meliputi:

1. Pemberian pengantar materi dan penyampaian tujuan pembelajaran 
2. Pemberian LKS (dikerjakan kelompok)

3. Jawaban dicocokkan dengan kunci jawaban yang tersedia

4. Pemberian LKS (dikerjakan secara individu)

5. Ditukar dengan kelompok lain untuk dicocokkan sesuai kunci jawaban yang tersedia

6. Pemberian penghargaan atau sertifikat

7. Observasi

Bersama dengan dilaksanakan tindakan, peneliti mengamati proses pelaksanaan tindakan dan akibat yang ditimbulkan. Data atau informasi yang dikumpulkan melalui observasi adalah hasil belajar siswa, keaktifan, keberanian, kerjasama, dan ketepatan serta menganalisis data dari hasil observasi.

8. Refleksi

Berdasarkan data hasil opservasi dan data hasil belajar siswa tersebut, peneliti melakuakan refleksi atas tindakan yang telah dilakukan. Jika pada hasil repfleksi I menunjukkan perlu adanya perbaikan, maka akan dilakukan penyempurnaan pada sklus II.

\section{Siklus II}

Seperti pada siklus I, pada siklus II terdiri atas proses silkus dengan tahap tahap yang meliputi perencanaan, tindakan, pengamatan, dan refleksi. Aktifitas pada siklus II ini sangat tergantung pada pelaksanaan siklus I.

\section{a. Perencanaan}

Pada rencana siklus II, kegiatan yang dilaksanakan adalah menentukan alternatif pemecahan masalah untuk mengatasi kekurangan pada siklus I.

\section{b. Tindakan}

Pada tahap ini, peneliti melaksanakan tindakan seperti pada siklus I, hanya dilakukan perubahan sesuai hasil refleksi pada siklus I guna memperbaiki kekurangan pada siklus sebelumnya. Pelaksanaan tindakan dilakukan oleh peneliti.

\section{c. Observasi}

Bersama dengan dilaksanakan tindakan, peneliti melakukan pengamatan terhadap aktifitas pembelajaran penjulahan pecahan dalam menyelesaika operasi penjumlahan pecahan.

\section{d. Refleksi}

Pada tahap ini guru melakukan refleksi terhadap pelaksanaan siklus II dan menganalisis untuk membuat kesimpulan atas pelaksanaan pembelajaran penjum-lahan pecahan dalam peningkatan hasil belajar siswa kelas IV SDN Pagentan 05 Kecamatan Singosari Kabupaten Malang.

Teknik analisis data yang digunakan pada penelitian ini adalah teknik analisis data kuntitatif dan kualitatif, Teknik analisa data kuantitatif digunaka untuk instrumen lembar observasi. Hal ini dikaernakan data yang diperoleh melalui lembar observasi bukan angka, sehingga paparan data yang digunakan adalah deskripsi rinci akan temuan penelitian yang berhasil diperoleh. Sementara itu hasil nilai siswa dianalisis secara kuantitaitf dengan menggunakan cara jumlah benar dari siswa dikalikan 10 . Kemudian hasil tersebut dapat diketahui apakah nilai yang diperoleh siswa telah memenuhi SKBM, kemudian penulis menggubah angka yang diperoleh siswa menjadi prosentasi dengan rumus:

$$
\frac{\text { Jumlah siswa tuntas }}{\text { Jumlah seluruh siswa }} \times 100 \%
$$

Setelah data berhasil dianalisis, tahap yang dilakukan penulis adalah tahap pengecekan keapsahan temuan. Langkah ini digunakan untuk memperoleh penelitian yang valid dan dapat dipertanggung jawabkan kepada seluruh pihak yang bersangkutan. Pada proses ini penulis menggunakan pengamat teman sejawat sebagai vasilitator hasil temuan

\section{HASIL DAN PEMBAHASAN}

\section{A. Hasil Penelitian}

Penerapan Model TGT pada Siklus I

Penelitian ini dilaksanakan di SDN. Pagentan 05 yang beralamatkan di jalan Raya Panglima Sudirman No: 18 Singosari 
Kabupaten Malang. Penelitian dilaksanakan pada tanggal 4 dan 6 Februari 2017. Siswa yang hadir pada saat penelitian berlangsung adalah 40 anak terdri dari 13 siswa putri dan 27 siswa laki-laki. Tahapan awal yang dilakukan guru dalam hal ini adalah sebagai penulis, adalah menyiapkan RPP. Kemudian media lain yang di butuhkan seperti kotak undian, nomor undian, kertas warna, gunting dan lem, sedangkan pensil dan penggaris tersedia di siswa masing-masing. Selanjutnya peneliti neminta bantuan guru/teman sejawat yang berperan sebagai fasilitator. Guru yang berperan sebagai fasilitator adalah ibu Jaenab, SPd. Beliau adalah guru kelas VI SDN Pagentan 05. Observator hanya bertindak sebagai pengamat dan tidak aktif dalam proses pembelajaran di dalam kelas.

Pada awal kegiatan siswa terlihat kurang antusias dalam mengikuti pembelajaran di klsa, mereka seperti tidak tertarik, enggan dan kurang serius untuk menerima pelajaran dari guru. Langkah selanjutnya yang dilakukan guru adalah mengeliarkan kotak dan nomer undian. Dibagikanya kertas lipat, gunting dan lem, siswa mengambil pensil dan penggaris pada kotak pensil masing-masing. Secara berkelompok siswa di minta untuk membuat kartu bilangan Romawi dari huruf-huruf yang ada dalam huruf -huruf alfabetis seperti: I, V, X, C, L, D dan M. Rangkai dan tulis abjad-abjad tersebut menjadi angka Romawi.

Setelah diskusi kelompok siswa diminta mempresentasikan hasil diskusi di depan kelas dengan menunjukkan berbagai variasi susunan bilangan Romawi. Selanjutnya peserta dari kelompok lain menyatakan suatu bilangan, yang mempresentasikan menunjukkan bilangan Romawi yang di minta. Hal ini diulang sampai 5 kali untuk tiap kelompok, siapa yang dapat menjawab dengan benar akan mendapatkan poin, siapa yang dapat mengumpulkan poin paling banyak akan menjadi pemenang. Langkah selanjutnya, guru membagikan kepada masing-masing siswa untuk mengerjakan soal latihan.
Jumlah soal yang dibuat latihan adalah 10 soal terdiri 5 soal untuk utuk menulis huruf alfabet menjadi desimal dan yang lain sebaliknya dsri bilangan Romawi menjadi alfabet. Setelah semua siswa selesai mengerjakan soal latihan diperoleh hasil sebagai berikut dengan SKBM 70:

- Siswa yang tuntas : 28 siswa $=\frac{28}{40} \mathrm{X}$ $100=70 \%$

- Siswa yang belum tuntas : 12 siswa = $\frac{12}{40} \times 100=30 \%$

Berdasarkan hasil analisis, dapat diketahui bahwa $70 \%$ siswa berhasil memperoleh nilai di atas SKBM , namun demikian $30 \%$ dari siswa masih memperoleh nilai dibawah SKBM.

\section{Penerapan metode TGT pada siklus II}

Setelah siklus I dilaksanakan, peneliti melakukan refleksi terhadap penelitian sebelumnya. Berdasarkan hasil observasi ditemukan kendala-kendala yang terjadi di lapangan, yakni:

1. Guru mengalami kesulitan mengawasi keseluruhan proses pembelajaran di dalam kelas, karena saat memandu satu kelompok, siswa dalam kelompok lain bersendau gurau membuat suasana kelas menjadi gadau.

2. Siswa agak kebingungan saat presentasi berlangsung terutama pada saat siswa dalam kelompok lain bertanya untuk memperagakan bilangan Romawi yang terdiri dari dua angka

3. Siswa masih terbawa dalam suasana belajar yang asing baginya sehingga membuat bingung saat giliran mempresentasikan di depan kelas yang mana situasi ini membuat siswa kurang percaya diri.

Berdasarkan kendala-kendala yang ada , peneliti dibantu oleh observator (teman sejawat) melakukan perbaikan pada RPP untuk siklus ke II. Perbaikanperbaikan yang dilakukan adalah: (1) Guru pengajar yaitu peneliti dibantu observator dalam proses pembelajaran di kelas. Observator diperkenankan membantu guru 
untuk mengawasi dan mengatur siswa jika terjadi keributan. (2) Guru memberi petunjuk yang lebih jelas kepada siswa agar siswa lebih mengerti dan tidak kebingungan lagi. (3) Guru lebih memberikan motivasi agar siswa lebih percaya diri untuk tampil saat mempresentasikan hasil diskusi di depan kelas, serta meberikan reward pada akhir proses pembelajaran kepada siswa setiap selesai mengerjakan sesuatu berupa pujian.

Pada kegiatan pelaksanan penelitian, guru lebih mempersiapkan materi beserta media yang dibutuhkan secara lengkap aat proses pembelajaran berlangsung. Lngkah selanjutnya adalah melaksanakan proses pembelajaran sesuai skenario yang ada dalam RPP. Pada awal kegiatan siswa masih ribut, guru mengkondisikan suasana lebih tenang dibantu observator dan memberikan teguran pada siswa yang ribut, dan suasana pembelajaranpun kembali menjadi tenang. Pada kegiatan inti, dikusi kelonpokpun berjalan dengan baik, masingmasing siswa mengerjakan tugasnya yaitu mencetak angka Romawi, menggunting dan menempelkan dengan rapi pada kertas warna pilihan masing-masing. Tiap kelompok nampak asyik menyelesaikan tugas masing-masing, sampai tiba waktunya untuk presentasimereka dengan tertib mengambil no undian yang diwakili ketua masing-masng kelompok. Dalam setiap tampilan di depan kelas untuk mempresentasikan tidak nampak malumalu, dengan ras percaya diri yang tinggi tiap tampilan selalu mendapat aplus yang meriah. Gurupun tak lupa memberikan acungan jempol sebagai penghargaan.

Pada kegiatan individu, yaitu menjawab soal latihan yang diberikan guru, siswa dapat mengerjakan soal dengan tenang. Hasil yang diperoleh siswapun mengalami peningkatan. Hal tersebut dapat dibuktikan dengan prosentase siswa yang telah memenuhi SKBM yang ditetapkan sekolah Komite sekolah, seperti nampak pada perhitungan berikut ini dengan SKBM 70:
- Siswa yang tuntas : 37 siswa $=\frac{37}{40} \times 100$ $=92,5 \%$

- Siswa yang belum tuntas : 3 siswa $=$ $\frac{3}{40} \times 100=7,5 \%$

Berdasarkan hasil analisis, dapat diketahui bahwa, prosentase siswa yang telah tuntas SKBM adalah 92,5\%. Sementara itu hanya terdapat 7,5\% siswa yang belum memenuhi SKBM yang telah ditentukan. Hal tersebut dapat diketahui bahwa, prosentase nilai ketuntasan siawa mengalami peningkatan dari siklus sebelumnya. Jika dibandingkan dengan perolehan nilai siswa pada ulangan sebelumnya, dibandingkan belajar dengan menggunakan model Permainan ( $T G T$ ) pada siklus I dan siklus II, maka peningkatan yang tercapai adalah sebagai berikut:

Tabel 1. Perbandingan Prosentasi Siswa yang Belum Tuntas dan Tuntas

\begin{tabular}{lcc}
\hline \multicolumn{1}{c}{ Tahapan } & $\begin{array}{c}\text { Jumlah Siswa } \\
\text { Tuntas }\end{array}$ & $\begin{array}{c}\text { Jumlah Tidak } \\
\text { Tuntas }\end{array}$ \\
\hline Nilai sebelumnya & $57,5 \%$ & $42,5 \%$ \\
\hline Siklus I & $70 \%$ & $30 \%$ \\
\hline Siklus II & $92,5 \%$ & $7,5 \%$ \\
\hline
\end{tabular}

Berdasarkan tabel 1 dapat diketahui bahwa terdapat peningkatan yang signifikan antara siswa tuntas pada mata pelajaran Matematika materi Pemecahan Masalah Bilangan Romawi. Peningkatan yang dialami siswa padasiklus I dan siklus II adalah 20\%, sementara itu jika dibandingkan dengan nilai sebelumnya, yang tidak menggunakan metode Permainan atau (TGT) peningkatan nilai adalah sejumlah $35 \%$.

\section{B. Pembahasan}

Berdasarkan pemaparan diatas, dapat diketahui bahwa guru berhasil menerapkan metode TGT pada mata pelajaran Matematika untuk materi Pemecahan Masalah Bilangan Romawi. Pada proses pembelajaran guru membagi siswa dalam bentuk kelompok - kelompok kecil antara 6-7 anak, untuk selanjutnya siswa berdiskusi sesuai tugas masingmasing. Sesuai tujuan model $T G T$ yaitu : (a) 
memberi kesempat an kepada siswa untuk mengembangkan kemampuan memecahkan masalah secara rasional, (b) mengembangkan sikap social dan semangat bergotong royong (c) mendinamisasikan kegiatan kelompok dalam belajar sehingga setiap kelompok merasa memiliki tanggung jawab, dan (d) mengembangkan kemampuan kepemimpinan dalam kelompok tersebut ( Dimyati dan Mundjiono, 2006).

Berdasarkan hasil observasi pada proses pembelajaran di dalam kelas, dapat di diketahui bahwa setiap siswa memiliki kesempatan untuk mengungkapkan pemahaman materi kepada teman lain melalui team presentasi. Hasil nilai yang diperoleh siswa dengan menggunakan model Permainan (TGT) pada mata pelajaran Matematika materi Pemecahan Masalah Bilangan Romawi, dapat diketahui bahwa terdapat peningkatan nilai. Hasil analisis nilai siswa kelas IV SDN Pgentan 05 Tahun Ajaran 2016/2017 terdapat peningkatan $35 \%$ dari jumlah siswa yang tuntas SKBM pada tahun sebelumnya. Sementara itu pada siklus II jumlah siswa yang tuntas juga mengalami peningkatan jika dibandingkan dengan siklus I.

Dengan tercapainya nilai SKBM dapat diketahui bahwa siswa mampu menguasai kompetensi dasar (KD) yang terdapat pada materi Pemecahan Masalah Bilangan Romawi. Hal ini sesuai dengan Silabus pembelajaran SD untuk mata pelajaran Matematika klas IV , yakni siswa mampu membaca bilangan Romawi ke dalam bilangan cacah atau sebaliknya dari bilangan cacah menjadi bilangan Romawi. Namun demikian terdapat kendala yang dialami guru dan siswa pada saat proses pembelajaran berlangsung saat menggunakan metode Permainan (TGT) ini, kendala-kendala tersebut adalah:

1. Dalam model pembelajaran ini, harus menggunakan waktu yang cukup lama.

2. Dalam model pembelajaran ini, guru dituntut untuk pandai memilih materi pelajaran yang cocok untuk model ini.
3. Guru harus mempersiapkan model ini dengan baik sebelum diterapkan.

Penjelasan di atas merupakan hasil penerapan metode TGT pada mata pelajaran Matematika kelas IV pada materi Pemecahan Masalah Bilangan Romawi. Selanjutnya peneliti akan mengulas kesimpulan dari hasil penelitian yang sudah dilaksanakan serta akan diuraikan pula saran-saran dari penulis untuk mengatasi kendala dan kekurangan-kekurangan yang terjadi selama proses penelitian tersebut.

\section{PENUTUP}

Berdasarkan hasil pembahasan pada bab IV dapat disimpulkan bahwa guru beserta siswa kelas IV SDN. Pagentan 05 Tahun Ajaran 2016/2017 berhasil melaksanakan pembelajaran Matematika pada materi Pemecahan Masalah Bilangan Romawi dengan menggunakan model TGT . Penelitian dilaksanakan dalam 2 siklus. Pada siklus I terdapat beberapa kendala, yakni: suasana kelas ramai dan guru tidak dapat memantau keselurukan siswa yang terbagi dalam ba kelompok - kelompok kecil. Selain itu, siswa belum mengerti dengan prosedur metode yang dilaksanakan. Hal ini berdampak pada alokasi waktu yang tidak sesuai dengan rencana yang sudah ditentukan.

Atas pengalaman yang terjadi pada siklus I, peneliti melaksanakan perbaikan pada siklus II. Perbaikan yang dilakukan yaitu, guru dibantu seotang teman sejawat/ observator untuk memantau dengan seksama, guru memberikan motivasi pada siswa untuk lebih serius dan fokus dalam mengikuti proses pembelajaran. Selain itu guru memberikan arahan yang lebih detail dan lebih rinci dalam memandu langkahlangkah yang harus diperankan siswa saat presentasi di depan kelas. Sebagai hasil belajar siswa pada siklus II, terdapat peningkatan hasil belajar siswa. Peningkatan yang dialami adalah $20 \%$. Sementara itu jika dibandimgkan dengan nilai belajar siswa sebelumnya terjadi peningkatan sebesar 35\%. Dari penjelasan di atas dapat disimpulkan bahwa, model 
TGT dapat meningkatkan minat serta hasil nilai belajar siswa kelas IV SDN. Pagentan 05 Tahun Ajaran 2016/2017 pada mata pelajaran Matematika, khususnya pada materi Pemecahan Masalah Bilangan Romawi. Hal ini membuktikan bahwa hipotesa tindakan pada penelitian ini benar.

\section{DAFTAR PUSTAKA}

Aeni, Risky. (2012). Model Pembelajaran Kooperatif Tipe TGT (Teams Games Tournament): http://rizardian.blogspot.com (Sabtu, 8 November 2016 pukul 09:39)

Anwar, Nhing. Makalah model pembelajaran kooperatif: http://nhingzanwar.blogspot.com/2013/05/makala h-model-pembelajaran

kooperatif_21.html (30 November 2016 pukul 10.00WIB)

Arikunto, Suharsini. (2002). Prosedur Penelitian Suatu Tinjauan Praktek. Jakarta: Rineke Cipta.

Denamulyana.blogspot.co.id/2015/2/model .pembelajaran.kooperatif.tipe.html (12 Februari 2017 pukul 15.17 WIB)

Desy, Kartika Putri. (2013). Makalah model pembelajaran koopertaif TGT: http://desykartikaputri.wordpress.co m/2013/01/02/makalah-modelpembelajaran-tgt-teams-gamestournament/ (30 November 2016 pukul 10.00WIB)

Huda, Miftahul. (2013). Model-Model Pengajaran dan Pembelajaran. Yogyakarta: Pustaka Pelajar

Listyawan, Wawan. (2012). Model pembelajaran kooperatif TGT. http://www.wawanlistyawan.com (Sabtu, 8 November 2016 pukul 09:35).

Muljani, Prapti. (2017). Efektivitas Pembelajaran Inquiry Untuk Meningkatkan Hasil Belajar Siswa Kelas VI Materi Satuan Debit. Jurnal PTK dan Pendidikan, 3(1), 51-62.

Pratiwi dkk. (2013). Teams Games Tournaments $(T G T)$ : http://3bkelompok5.blogspot.com/
(Sabtu, 8 November 2016 pukul 09:30) 